Portland State University

PDXScholar

\title{
If It Is Unsightly, Is It Less Healthy? Understanding the Consumer's Desire for Aesthetically Perfect Produce
}

Dina VanderWaal

Portland State University

Follow this and additional works at: https://pdxscholar.library.pdx.edu/honorstheses

\section{Let us know how access to this document benefits you.}

\section{Recommended Citation}

VanderWaal, Dina, "If It Is Unsightly, Is It Less Healthy? Understanding the Consumer's Desire for Aesthetically Perfect Produce" (2017). University Honors Theses. Paper 495.

https://doi.org/10.15760/honors.498

This Thesis is brought to you for free and open access. It has been accepted for inclusion in University Honors Theses by an authorized administrator of PDXScholar. Please contact us if we can make this document more accessible: pdxscholar@pdx.edu. 
If it is Unsightly, is it Less Healthy? Understanding the Consumer's Desire for Aesthetically Perfect Produce

Dina VanderWaal

Thesis Adviser: Dr. Jacob Suher

Portland State University

18 August 2017 


\begin{abstract}
Attention on organic produce and food waste is becoming increasingly intense in the United States. Consumers typically prefer aesthetically perfect produce, forcing grocery stores to throw away blemished fruits and vegetables. Organic produce is typically more blemished than conventional produce. Little research has been done to examine the consumer's preference for conventional versus organic produce, and the point, if any, where consumers are more likely to choose one over the other. We conducted a controlled online study where we showed participants various organic and conventional apples with varying degrees of imperfections, and asked participants a series of questions about which they preferred. From this study, we learned that typically, consumers believe organic produce is healthier than conventional produce and are more willing to accept blemished organic produce when they know which is organic and which is conventional. If neither is labeled, consumers will then judge solely off the aesthetics of the apple. With this information, farmers may be able to sell more of their produce to stores than they previously thought while grocery stores will want to consider how they are labeling and marketing their produce.
\end{abstract}

\title{
Introduction
}

A significant trend in consumer behavior is consumers' increasing sensitivity to the types of foods they consume on a daily basis (Hartman, 2015). This increase in meticulous selection has influenced consumer decision making in the grocery store setting, more specifically, produce selection. In the produce section, consumers can find vibrant colors, a variety of assortments and rarely come across blemished or damaged produce. Misshapen produce, produce with blemishes and other signs of 'defects' are often overlooked and unwanted by the consumer (Tsui, 2014). The result, anywhere from 20 to 50 percent of the fruits and vegetables farmed never even make 
it to the grocery store display because they are unmarketable to consumers (Gunders, 2012). This desire for perfection in produce may be influenced by the consumer's hesitation: if it is unsightly, is it less healthy?

To answer this question, previous academic literature on consumer decision making and food manufacturing regarding produce has been centered around three ideas: consumers' desire aesthetically perfect produce, they perceive organic produce to be healthier than conventional, but organic produce is often less aesthetically perfect. As a result, what the consumer desires in produce may be contradictory. With the consumer's preference for "perfect produce", which is often grown with pesticides, and their belief that organic produce is healthier, what takes more precedence when making produce choices? And at what point are consumers willing to accept imperfect produce if it is organic?

To answer these questions, this thesis will review related literature and explain the methods of primary data collection in the form of a controlled study. We will focus on the consumer's perspective because the definition of what is "healthy" or nutritious varies and is often subjective. In a poll conducted by the New York Times and Morning Consult, nutritionists from the American Society for Nutrition and a sample of the general population were asked whether they thought certain foods were healthy. Foods like apples, kale, and oatmeal were considered healthy by most nutritionists and people. Variation showed in foods like granola, coconut oil, and frozen yogurt, which nutritionists deemed not particularly healthy while the public deemed them healthy (Quealy \& Sanger-Katz, 2016). There will always be variation in nutritional advice and it is often subjective. In support of this evidence, licensed Nutritionist Carolyn Denton wrote that nutrition in food is not about isolating a nutrient's effect on a person, rather in the examination of the entirety of that person's diet (Denton, 2016). 
Conducting research to determine what influences the consumers when choosing organic or conventional produce may help to lower the percentage of produce that is thrown away prior to even entering the grocery store doors (Gruber, Howleg, and Teller, 2016). We conducted a controlled study where consumers indicated their preferences when given the choice between organic and conventional apples and to determine at what point consumers were willing to accept blemished produce. We also tested whether they believed organic was healthier. Overall, the participants showed a preference for organic produce if it was labeled organic and believed it was healthier, even if it was slightly blemished, but preferred aesthetically prefect produce if it was not labeled.

\section{Literature Review}

\section{a. Organic}

To be labeled organic within the United States, produce must follow a set of standards defined by the National Organic Program ("National Organic Program"). Generally, organic produce is, "grown without synthetic pesticides or fertilizers or routine use of antibiotics or growth hormones" (Stave, et. al, 2012). Once the produce is passed as organic, it is given the "USDA Organic" seal. Attention on organic produce has been rekindled over the years and organic is believed by many to be a healthier option than non-organic (Aubrey \& Charles, 2012). In a poll conducted by Mintel, 72 percent of US consumers purchase organic foods because they believed it was healthier (“Over Half...", 2015). However, in a study conducted by Christopher Stave and his coworkers at Stanford University, they worked to determine whether organic food was safer or healthier than conventional food. Their study found that there is no significant evidence to support the belief that organic food is healthier (Stave, et. al, 2012). 
Since there is debate over whether organic produce is objectively healthier than conventional produce, recent studies have focused on determining consumers' subjective perceptions of organic foods. In a study conducted by Jesse Strzok and Wallace Huffman at Iowa State University, the consumer's willingness to pay more for organic food products was examined. Data was collected by auctioning off conventional and organic food products to determine how much the consumer was willing to pay. The study showed that the consumers were generally willing to pay more for organic products over conventional and demographical characteristics such as being in an environmentalist group or having an income above $\$ 76,000$ also increased their likelihood to pay more (Strzok \& Huffman, 2012). Consumers' willingness to pay more for organic foods is generally attributed to their beliefs that organic food (grown pesticide free) is better for the environment and welfare of animals. This willingness will also likely increase as consumers get older (Shafie \& Rennie, 2009). While determining if a consumer believes organic is healthier and are willing to pay more for it is important in understanding their decision making, these studies have not compared organic versus conventional produce to see if those findings still remain true when given multiple options. A study in the Journal of Food Distribution Research determined that despite consumers believing that organic produce is better for their health, less than 30 percent of respondents purchased it regularly (Byrne et. al., 2011).

\section{b. Imperfections}

Another significant factor that influences consumers' produce choices is the visual aesthetics of food. While the above studies indicated consumers are willing to spend more money on organic produce that they believe is healthier, it does not prove consumers will choose aesthetically perfect produce when in store. There have been few studies focused on the consumers' reluctance to purchase blemished or aesthetically displeasing produce. One of the 
few studies was conducted in five Northern European countries (Germany, Sweden, The Netherlands, Norway, and Denmark). They chose these countries due to their comparable urbanization, literacy rate, ecological footprint, and world-system position. They conducted their study by surveying 4,214 consumers, having each of them choose what they would prefer when given the choice between two items: one perfect and one sub-optimal. The results of the studies showed that consumers choose suboptimal products less than perfect options, but that preference is dependent on various situations. In the instance of grocery shopping, produce with color deviation (fruit with discolored spots) was very rarely accepted as consumers may associate blemished produce as unsafe to eat, and bad tasting. Since these all influence the consumer's willingness to buy, consumers will be less likely to buy blemished produce in stores (de Hooge, et. al, 2016).

Another study examined consumers' purchase intentions when given the options of extremely abnormal, moderately abnormal, or normal fruits or vegetables. Nine hundred and sixty-four Danish consumers were given the choice between normal, moderately abnormal, and extremely abnormal produce. They were then asked how likely they were to purchase each of the options. The results showed that extreme abnormalities in fruits and vegetables did influence the consumer intent to purchase and they showed a preference for less blemished produce, or normal produce (Loebnitz et al., 2015). This desire for produce with no imperfections and an increase in the customer's willingness to pay for organic was also found in a study conducted by Chengyan $\mathrm{Yu}$, an assistant professor at the University of Minnesota - Twin Cities. Dr. Yue examined the consumer's preference for aesthetically perfect or blemished apples and the relation between organic and their willingness to pay. Consumers overwhelmingly preferred the aesthetically perfect produce, which was the conventional option, but responded that they would be more 
willing to pay a higher price for organic produce if it was unblemished, due to their belief that it is healthier (Yue, Chengyan, Helen Jensen, et. al, 2007). Overall, studies on imperfections in produce have typically found that consumers prefer unblemished produce and will be more willing to pay for organic produce.

\section{c. Organic produce is more likely to be imperfect}

The two aforementioned points are important because they may lead to conflicting predictions in real-world settings like grocery stores, where most food waste occurs. Like stated previously, anywhere between 20 to 50 percent of produce never makes it to the store (Gunders, 2012). Organic produce is more likely to be blemished because unlike conventional produce, it is often grown without pesticides or with USDA allowed pesticides (Porterfield, 2016). In an article posted by the Washington Post, Beth Mitcham, a post-harvest researcher at the University of California Davis said that research has showed that produce is more likely to be rejected if it is blemished versus poor tasting or unripe. John Navazio, a plant breeder, made the argument that organic produce is often grown at a different standard than that of conventional, which is why it is more likely to be accepted as imperfect. Commercially grown conventional produce is grown in an industrial model that has been treated with pesticides and fertilizers. Organic produce resists insects and other elements more naturally, through its genetic diversity, which is why organic produce is often more blemished (Miller, 2013). Because of this, it is more common to find organic produce to have imperfections, as it must ward off insects and pest more naturally and must be less reliant on conventional methods. After examining past literature, organic produce is more likely to be blemished, but consumers believe organic is healthier. However, consumers prefer aesthetically perfect produce which is more often conventional rather than organic. Some of these preferences may contradict each other. 


\section{Hypothesis Development}

Based on the aforementioned studies, we expect the interaction between produce aesthetics and organic labelling to influence consumers' choices. Consumers have shown a preference for aesthetically perfect produce, which is often conventional and grown with pesticides. However, they hold onto a belief that organic, which is often grown without pesticides, is healthier though often blemished. Perceived nutritional value may influence what takes precedence when the consumer decides between organic or conventional produce. In a study conducted by David Bunn, consumers were more likely to accept blemished produce if they knew the aesthetically perfect produce was sprayed with pesticides (Bunn et. al, 1990). However, aspects like torn or damaged packaging, or blemishes, may deter consumers from purchasing a product all together due to the fear of contamination (White et al., 2016). Both these factors may define the point at which consumers are willing to accept or reject imperfect produce. In this study, we will be focusing on cosmetic defects on the produce itself.

The purpose of collecting primary data in this thesis process is to better understand what influences the consumer by specifically defining the role, if any, these two variables play in consumer perception and the potential impact on their decision-making process. The Dutch study mentioned in the previous section looked to define when the consumer was more likely to choose foods that deviated from the standard. When given the choice of a blemished apple or an aesthetically perfect apple, consumers almost never chose the blemished apple (de Hooge et al., 2017). However, the study, while it helped to determine that the customer would very rarely choose blemished produce, did not examine the consumer's preference when given the option of either organic or conventional. In the study conducted by Chengyan Yue, referenced in the literature review section, consumers were asked to decide between an aesthetically perfect 
conventional apples or organic apples with sooty black and flyspeck (SBFS) disease (a cosmetic defect), often found on organic apples. The results showed that consumers very rarely prefer the apples with SBFS despite organic being perceived as healthy (Yue, Chengyan, Helen Jensen, et. al, 2007). In our study, we want to determine the effect, if any, of the consumer's desire for perfection and the belief that organic is healthier has on their decision-making process.

These are the hypotheses for the use of apples as the focal stimulus:

1) Consumers will perceive organic apples to be healthier.

2) When consumers have a choice between a labeled organic apple or a labeled conventional apple, people will prefer organic unless it is very blemished.

3) Consumers will perceive perfect conventional apples as healthier than very blemished organic or somewhat blemished organic apples when they do not know which is organic or which is non-organic.

Our study will look to define why consumers prefer the apples they do. Based on our hypothesis, we believe that we will find similar responses to the previous studies. However, we are looking to collect reasoning from our participants as to why they prefer one over the other. We collected and analyzed participants' responses in a controlled study to determine their judgements and preferences.

\section{Methods}

\section{a. Respondents and design}

26 people participated in this study. They were recruited online through email and Facebook. Online recruiting methods were used because it was easier to provide the instructions for the survey and the URL. We expected the demographics of the respondents to be similar, because most respondents who are online are younger, meaning the outcome of the study could 
be relatable to younger consumers. However, variation in diets may have had a significant impact in the differences of responses. Overall, those who volunteered to participate in the study were a small yet diverse sample of consumers. Two participants were between 18 and 20 years old, fourteen were within the 21 to 24 year old age bracket, and eight were older than 25 . The participants were given a private link to a Qualtrics survey, which was 40 questions long, and took them approximately 5 to 10 minutes to complete. The survey was the same for each participant, the only variance dependent on their answers to certain questions (when participants choose apples, they would be asked why they choose the one they did; (see Appendix 1). Therefore, if one participant chose Apple 1 and one participant chose Apple 2, the first participant was asked why they chose Apple 1 and the second participant was asked why they chose Apple 2. All 26 participants' answers were used.

\section{b. Study Design}

To determine the participants' preferences when given sets of different apples, an experimental design was constructed. During the first section of the choice task, participants were shown two aesthetically perfect conventional apples and told one was organic and one was not. Participants were told that one apple was organic and one apple was conventional, despite both being conventional, to either prove or dispute the claim that many people perceive organic to be healthier when there is little evidence to support that claim. By having two identical apples, participants had to choose based off their perception rather than physical determinants. They were then asked to give their opinion on which apple they believed was healthier for them and which they would be more likely to choose in a grocery store setting and to give their opinions as to why they preferred the apple they chose. This section was designed to test the first hypothesis, that consumers will prefer the organic apple. 
In the second section of the survey, participants were shown a blemished organic apple and an aesthetically perfect conventional apple and asked to choose which one they would prefer in order to determine if consumers would accept aesthetically imperfect produce. This section was used to test the second hypothesis. By having a blemished organic apple and an aesthetically perfect conventional apple, both of which were conventional apples, we were looking to see if the organic label still had a higher influence on the consumer than blemishes.

In the third section of the study, we showed each participant a conventional apple without telling them if it was organic or conventional. At random, we selected between a very blemished, somewhat blemished, or aesthetically perfect organic apples that were rotated in and out, while the conventional apple always remained. The participants were then asked to choose which apple they believed to be the healthiest and which apple they would have been most likely to choose at the grocery store. In this section, participants were not told what apples were organic and what apples were conventional. We wanted to measure their preferences when there were distinct physical differences with the different apples. This section was created to test the third hypothesis. With no labels to influence the consumer's decision, we wanted to determine the consumer's preferences when they only had physical determinants to influence them.

\section{Results}

The results of the first section of the study showed that an overwhelming majority, 77 percent, of participants chose the apple labeled organic as the one they would be more likely to choose at a grocery store when given the option between an aesthetically perfect organic and conventional apple. Twenty-three percent of the participants chose Apple 1, the apple labeled conventional, as the apple they believed to be healthier and more likely to purchase at the 
grocery store. From the 77 percent of participants that chose Apple 2, 58 percent of them wrote that they would choose the second apple because it was organic and overall, looked better.

However, in Section 2, the participants were given the option between a labeled organic apple that was blemished and an aesthetically perfect conventional apple. A majority chose the blemished organic apple, though the results were closer. Fifty-four percent of the participants preferred Apple 1, the organic and blemished apple. Fourty-six percent of the participants chose Apple 2 as the one they preferred. When comparing the results of Section 1 to Section 2, the blemishes drastically decreased the participants' desire to choose the organic apple. However, in this instance, participants were more willing to accept aesthetically imperfect organic apples. Of the 54 percent of participants who choose Apple 1, 79 percent said they chose it because it was labeled organic. Of the 46 percent of the participants that chose Apple 2, 63 percent chose it because it had no blemishes.

In Section 3, there were two different sets of three apples, none of which were labelled organic or conventional. The conventional perfect apple was in both sets, while two different organic apples with varying degrees of blemishes were shown. The participants were not told which is organic and which is conventional. The first set had an aesthetically perfect apple represented by Apple 1, a very blemished apple represented by Apple 2, and a somewhat blemished apple represented by Apple 3. When asked which two apples they preferred, 81 percent of the participants chose Apple 1 and Apple 3. The majority chose these two apples because of they had few brown spots and looked healthier. When asked which single apple of the three they would be most likely to choose at a grocery store, 50 percent of the participants chose Apple 1, the aesthetically perfect apple. In the second set of apples, when asked which two apples they preferred, Apple 1 and Apple 3 were preferred by 35 percent of the participants, 
Apple 1 being the overall favorite, with 81 percent picking it as the single apple they would choose at a grocery store. Most participants wrote that they preferred Apple 1 because it is aesthetically perfect while the other apples had blemishes.

\section{Discussion}

The results of this controlled study are similar to previously written literature about the consumer's preference when it comes to aesthetically perfect produce. The findings of the present research suggest that consumers perceive organic as healthier when compared to conventional produce, and will likely prefer organic produce over conventional produce when it is labeled. Consumers also showed that they were more willing to accept blemishes on organic produce than what we thought. They did not believe it was less healthy because of its blemishes because they perceived organic as healthier. However, if the produce is not labeled, consumers will judge the health and quality of the produce by its aesthetics. Consumers are more likely to choose aesthetically perfect produce when they are unsure what is organic and what is conventional. Overall, the perception of health in regard to organic produce appears to play the strongest role in the consumer's decision-making process when they have no other information other than labels. Consumers generally believe organic is healthier and will gravitate toward organic labeled produce when given the option. When there are no labels on produce and consumers do not know which is organic and which is conventional, they will gravitate toward whatever has fewer blemishes as it looks the most appealing.

\section{Theoretical Contributions, Substantive/Managerial Implications, and Future Research}

Consumers often times overlook produce that is aesthetically unpleasing, refusing to buy produce that is blemished, misshapen, or discolored. Because of this, ten percent of all in store food across the United States is wasted every year (Husted, 2014). The present findings provide a look into the possibilities of reducing the amount of grocery store food waste in the United 
States. Our study concluded that when it comes to organic produce, consumers are more lenient on their desire for perfection. For this reason, grocery stores and farmers could reexamine the tight restrictions on bringing imperfect organic produce to include more produce with slight blemishes.

While consumers are more likely to choose the aesthetically perfect produce option overall, our study indicated that many consumers are also influenced by an organic label. In the first section of our survey, consumers overwhelming preferred the "organic apple" over the conventional apple when both shared very few distinguishable characteristics. Our study also suggested that when consumers are unsure what is organic and what is conventional, they will pick the aesthetically perfect produce. Further examining the role of grocery store signage on the consumers' decision making may help connect the role of labeling on consumer preference. When asked which apples they believed to be organic and which apples were conventional, many participants could not answer, solely based off aesthetics. The participants who did respond generally chose the more blemished apples as the organic ones. However, our study showed that consumers are more likely to accept blemished produce if it is organic. Continuing research on the effects of the consumers' perception of organic being unsightly may benefit both grocery stores and organic farmers who are looking to define a more specific threshold between acceptable and unacceptable produce. Slowly integrating more blemished produce, while it carries a bit of risk, would also help grocery stores define the point at which consumers are no longer willing to accept the produce. While our study included apples at both ends of the spectrum, aesthetically perfect and very blemished, we were not able to define the point at which produce is no longer deemed acceptable. In doing this, it would be easier to decide which produce is marketable to consumers rather than following the assumption that any blemishes are 
unacceptable. Continuing to understand and discover what influences the consumers' decisionmaking process will help us combat the ongoing food waste problem within the United States.

\section{Conclusion}

In conclusion, consumers do show a preference toward aesthetically perfect and organic produce. They also show more acceptance toward blemished produce if they know it is organic and will not automatically believe it to be less healthy. Though it is widely debated whether organic is actually better for our health, organic labels are highly influential within the consumer's decision making process. Continuing to evaluate how the consumer is affected by grocery store signage and defining the point at which consumers are no longer willing to accept blemished produce will help grocery stores both better cater to the needs of their customers and lessen the amount of perfectly edible produce thrown away every day. 


\section{References}

"Adult Obesity in the United States." The State of Obesity. The State of Obesity, 1 Sep. 2016. Web. 6 June 2017. <www.stateofobesity.org>

Aubrey, Allison and Dan Charles. "Why Organic Food May Not Be Healthier for You." NPR. NPR, 4 Sep. 2012. Web. 6 June 2017.

Byrne, Patrick, Ulrich Toensmeyer, Carl German, and H. Reed Mueller. "Analysis of Consumer Attitudes Toward Organic Produce and Purchased Likelihood." Journal of Food Distribution Research, vol. 22, no. 2, 1991, pp. 49-62.

Chan, Elisa, Robert Kwortnik, and Brian Wansink. "McHealthy: How Marketing Influences Healthy Food Choices.” Cornell Hospitality Quarterly, vol. 58, no. 1, 2017, pp. 7-22.

de Hooge, Ilona, et al. "This Apple is Too Ugly for Me! Consumer Preference for Suboptimal Food Products in the Supermarket and at Home." Food Quality and Preference, vol. 56, no. 56, 2017, pp. 80-92.

Denton, Carolyn. "Why Does Nutrition Advice Change?" University of Minnesota. University of Minnesota, 2016. Web. 6 June 2017.

Gunders, Dana. "Wasted: How America Is Losing Up to 40 Percent of Its Food from Farm to Fork to Landfill.” New York: National Resources Defense Council, 2012. Print.

Haws, Kelly, and Joseph Redden. "Healthy Satiation: The Role of Decreasing Desire in Effective Self-Control.” Journal of Consumer Research, vol. 39, no. 5, 2013, pp. 1110-1114.

The Hartman Group. "Consumer Trends in Health and Wellness.” Forbes. Forbes, 19 November, 2017. Web. 6 June 2017.

Husted, Kristofor. "Supermarkets Waste a Ton of Food as They Woo Shoppers.” NPR. NPR, 25 Sep. 2014. Web. 1 Aug. 2017.

Kovar, Elizabeth. “Are Americans Becoming More Health Conscious?” American Council on Exercise. ACE, 27 May 2016. Web. 6 June 2017.

Loebnitz, Natascha, Geertje Schuitmea, and Klaus Grunert. "Who Buys Oddly Shaped Food and Why? Impacts of Food Shape Abnormality and Organic Labeling on Purchase Intentions." Psychology and Marketing, vol. 32, no. 4, 2015, pp. 408-421.

Mai, Robert, and Stefan Hoffmann. "Taste lovers versus nutrition fact seekers: How health consciousness and self-efficacy determine the way consumers choose food products." Journal of Consumer Behaviour, vol. 11, no. 4, 2012, pp. 316-328. 
Miller, Daphne. "Why Perfect-Looking Produce can be Less than Ideal." Washington Post. Washington Post, 17 Sep. 2013. Web. 1 Aug. 2017.

"Over Half of US Consumers Think Organic Labeling is an Excuse to Charge More." Mintel. Mintel, 13 May 2015. Web. 6 June 2017.

Pimentel, David. "Environmental and Economic Costs of the Application of Pesticides Primarily in the United States." Environment, Development and Sustainability, Vol. 7, no. 2, 2005, pp. 229-252.

Porterfield, Andrew. "Myth Busting on Pesticides: Despite Demonization, Organic Farmers Widely Use Them." Genetic Literacy Project. n.p., 1 Dec. 2016. Web. 1 Aug. 2017.

Quealy, Kevin and Margot Sanger-Katz. "Is Sushi 'Healthy'? What About Granola? Where Americans and Nutritionists Disagree.” New York Times. New York Times, 5 July 2016. Web. 6 June 2017.

Shafie, Farah and Denise Rennie. "Consumer Perceptions towards Organic Food." Procedia, vol. 49, no. 1, pp. 360-367.

Smith-Spangler, Crystal, Brandeau, Margaret, et. al. "Are Organic Foods Safer or Healthier to Eat than Conventional Alternatives?" Annals for Internal Medicine, Vol. 157, no. 5, pp. 348-366.

Strzok, Jesse and Wallace Huffman. "Willingness-to-Pay for Organic Food Products and Organic Purity: Experimental Evidence." The Journal for Agrobiotechnology Management and Economics, Vol. 18, no. 3, 2012, pp. 345-353.

Thompson, Gary, and Julia Kidwell. "Explaining the Choice of Organic Produce: Cosmetic Defects, Prices, and Consumer Preferences." American Journal of Agricultural Economics, Vol. 80, no. 2, 1998, pp. 277-287.

Tsui, Bonnie. "Getting Over Our Preference for Perfect Produce.” Newsweek Global, vol. 162, no. 17,2014 , pp. $1-5$

Yue, Chengyan, Helen Jensen, et. al. "Estimating Consumer's Valuation of Organic and Cosmetically Damaged Apples." Hort Science, vol. 42, no. 6, 2007, pg. 1366-1371.

Zhu, Chen, Rigoberto Lopez, and Xiaoou Liu. "Information Cost and Consumer Choices of Healthy Food." American Journal of Agricultural Economics, vol. 98, no. 1, 2016, pp. 41-53. 
Appendix 1 - Study

HON 403

Section 1

Portland State University Consent to Participate in Research Produce Preference Study General Public July 26, 2017

Introduction: You are being asked to participate in a controlled research study that is being done by Jacob Suher, the Principal Investigator and marketing professor, and Dina VanderWaal, a student, at Portland State University in Portland, Oregon. This research is studying consumer's behavior and preference for produce. This form will explain the study and possible risks and benefits to you. We advise you to take your time when deciding whether to participate. If you have any questions, please contact us with any questions or concerns. If you decide to participate, the following things will occur: You will be given several different apples from a local grocery store and asked a series of questions in which you are to write your response. How long will I be in this study?The study will be approximately 5 minutes What are the risks or side effects of being in this study? There are risks of stress, emotional distress, inconvenience, loss of time, and possible loss of privacy and confidentiality associated with participating in this study. For more information, ask the investigators. What are the benefits to being in this study? There are no direct benefits of participating in this study. You do not have to participate in this study. What are the alternatives to being in this study? You do not have to participate in this study, How will my information be kept confidential? We will take the necessary measures to keep your information safe, but cannot guarantee confidentiality of all study responses. You will not be asked to provide any information that would link you to your responses. Information contained in your study records is used by study staff. The Portland State University Institutional Review Board (IRB) that oversees human subject research and/or other entities may be permitted to access your records, and there may be times when we are required by law to share your information. It is the investigator's legal obligation to report child abuse, child neglect, elder abuse, harm to self or others or any life-threatening situation to the appropriate authorities, and; therefore, your confidentiality will not be maintained. Your name will not be used in any published reports about this study. Will I be paid for taking part in this study? You will not be paid to participate in this study. Can I stop being in the study once I begin? Your participation is completely voluntary and you may stop at any point without any penalty. If you have any questions, concerns, or complaints at any time you make contact Jacob Suher at (503)-725-9875 or Dina VanderWaal at (763)-331-5821. If you have questions regarding your rights as a research participant, you may call the PSU Office for Research Integrity at (503) 725-2227 or 1(877) 480-4400. The ORI is the office that supports the PSU Institutional Review Board (IRB). The IRB is a group of people from PSU and the community who provide independent oversight of safety and ethical issues related to research involving human participants. For more 
information, you may also access the IRB website at https://sites.google.com/a/pdx.edu/research/integrity.

CONSENT You are making a decision on whether to participate in this study. By completing this survey, you are agreeing to participate in this study.You are making a decision on whether or not to participate in this study.

I agree to participate in this study. (1)

Page Break

Instructions :You will be shown various pictures of produce and asked to answer a few questions. Your responses will be anonymous.

Page Break

Section 1
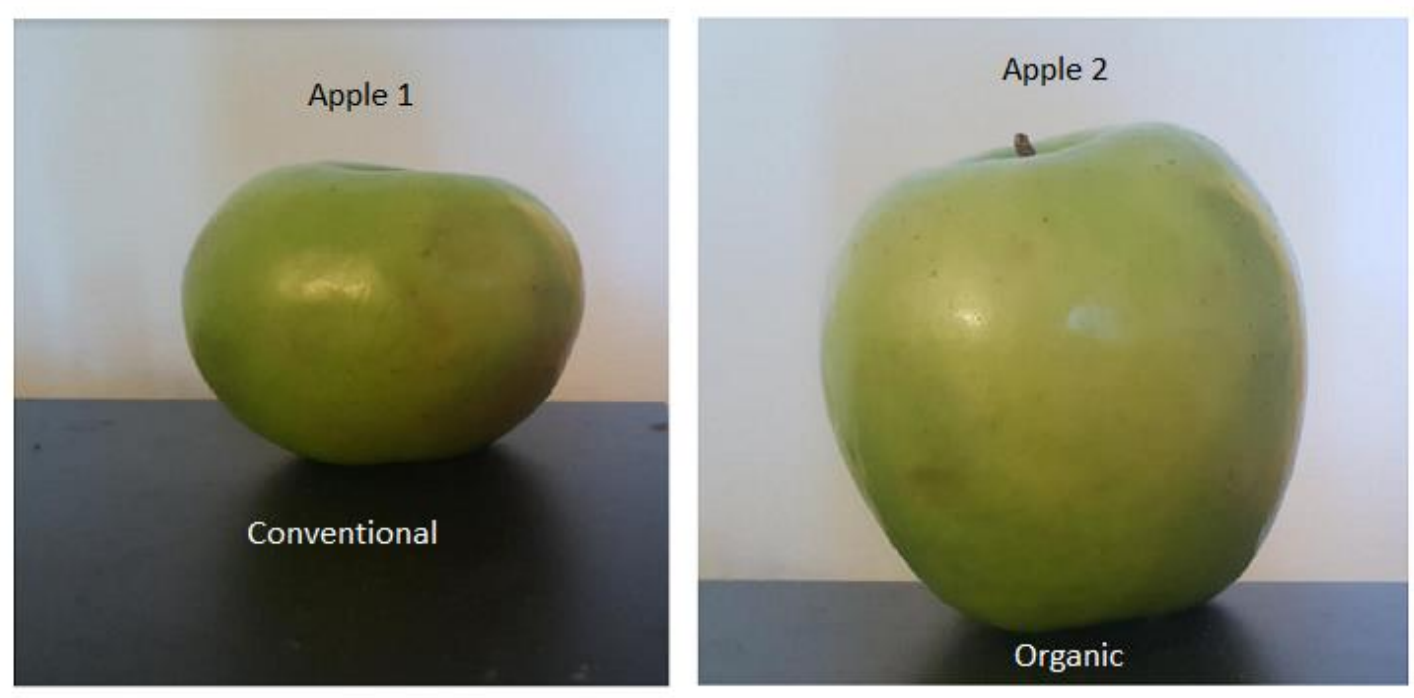
1 Which apple do you think is healthier for you?

\section{Apple 1 (1)}

Apple 2 (2)

2 Which apple would you be more likely to buy in a grocery store?

Apple $1(1)$

Apple 2 (2)

\section{Display This Question: \\ If Which apple do you think is healthier for you? Apple 1 Is Selected}

3 Why did you choose the Apple 1 in Question 2?

\section{Display This Question:}

\section{If Which apple do you think is healthier for you? Apple 2 Is Selected}

3 Why did you choose the Apple 2 in Question 2?

\section{Display This Question: \\ If Which apple would you be more likely to buy in a grocery store? Apple 1 Is Selected}

4 What would have to be different, if anything, about Apple 2 for you to purchase it at a grocery store? 
Display This Question:

If Which apple would you be more likely to buy in a grocery store? Apple 2 Is Selected

4 What would have to be different, if anything, about Apple 1 for you to purchase it at a grocery store?

\section{Page Break}

\section{End of Block}

\section{Section 2}
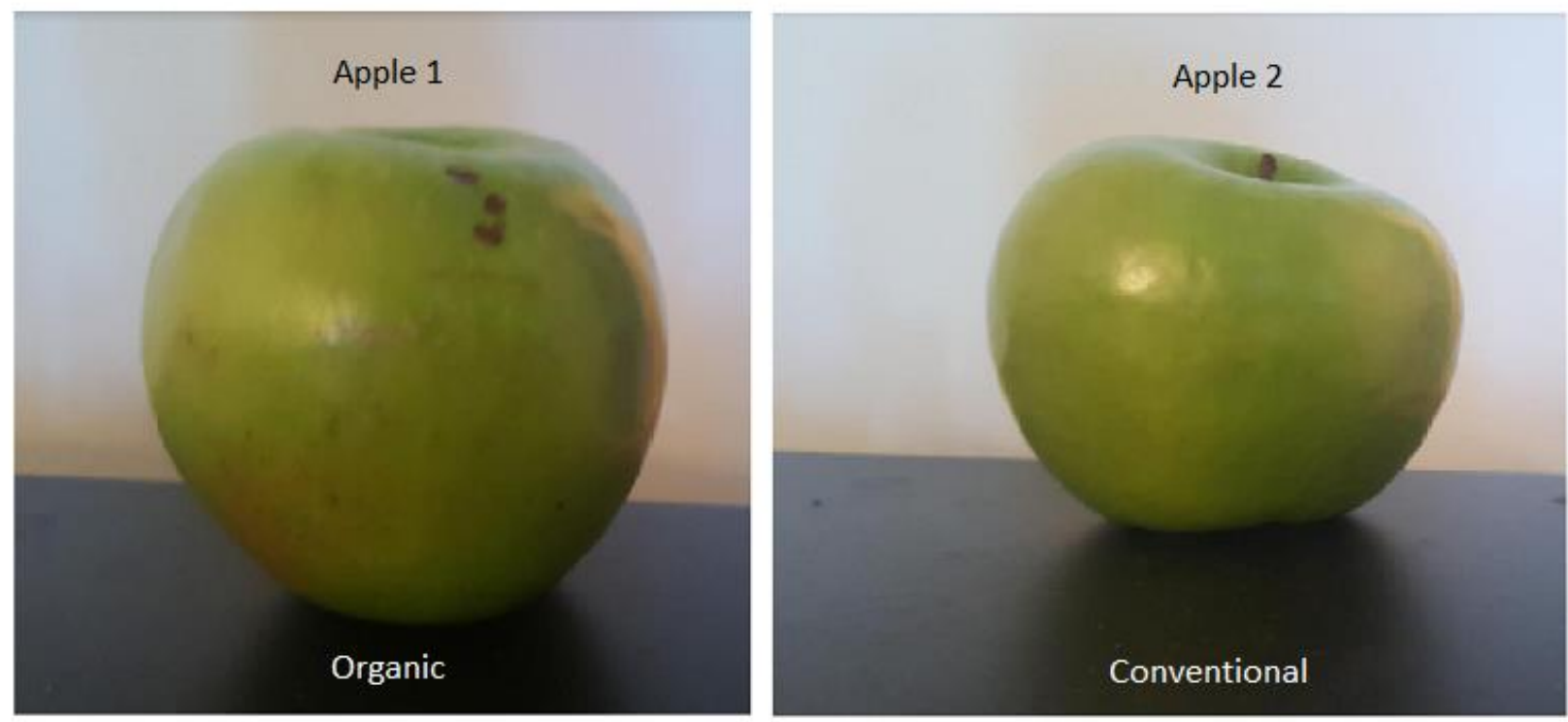

5 Which apple do you think is healthier for you?

\section{Apple 1 (1)}

Apple 2 (2) 
6 Which apple would you be more likely to choose at a grocery store?

\section{Apple 1 (1)}

Apple 2 (2)

\section{Display This Question: \\ If Which apple do you think is healthier for you? Apple 1 Is Selected}

7 Why did you choose Apple 1 in Question 5?

\section{Display This Question: \\ If Which apple do you think is healthier for you? Apple 2 Is Selected}

7 Why did you choose Apple 2 in Question 5?

\section{Display This Question: \\ If Which apple would you be more likely to choose at a grocery store? Apple 1 Is Selected}

8 What would have to be different, if anything, about Apple 2 for you to purchase it at a grocery store?

\section{Display This Question:}


8 What would have to be different, if anything, about Apple 1 for you to purchase it at a grocery store?

\section{End of Block}

Section 3
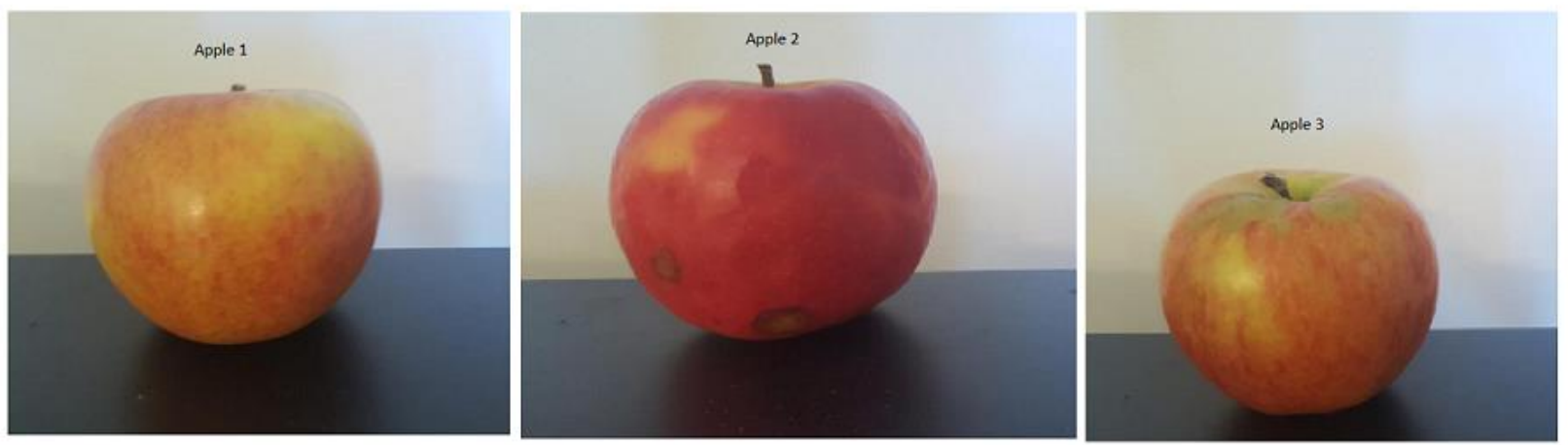

9 Out of these three apples, which two do you believe are healthier for you?

Apple 1 and Apple 2 (1)

Apple 1 and Apple 3 (2)

Apple 2 and Apple 3 (3)

10 Out of these three apples, which one would you be more likely to purchase at a grocery store?

Apple $1(1)$

Apple $2(2)$

Apple 3 (3)

\section{Display This Question: \\ If Out of these three apples, which two do you believe are healthier for you? Apple 1 and} Apple 2 Is Selected 
11 Why did you choose Apple 1 and Apple 2 in Question 6?

Display This Question:

If Out of these three apples, which two do you believe are healthier for you? Apple 1 and Apple 3 Is Selected

11 Why did you choose Apple 1 and Apple 3 in Question 6?

Display This Question:

If Out of these three apples, which two do you believe are healthier for you? Apple 2 and Apple 3 Is Selected

11 Why did you choose Apple 2 and Apple 3 in Question 6?

\section{Display This Question:}

If Out of these three apples, which one would you be more likely to purchase at a grocery store? Apple 1 Is Selected

12 What would have to be different, if anything, about the apples you said you would not purchase in a grocery store (Apple 2 and 3 ) for you to purchase them at a grocery store?

\section{Display This Question:}

If Out of these three apples, which one would you be more likely to purchase at a grocery store? Apple 2 Is Selected 
12 What would have to be different, if anything, about the apples you said you would not purchase in a grocery store (Apple 1 and 3) for you to purchase them at a grocery store?

\section{Display This Question:}

If Out of these three apples, which one would you be more likely to purchase at a grocery store? Apple 3 Is Selected

12 What would have to be different, if anything, about the apples you said you would not purchase in a grocery store (Apple 1 and 2) for you to purchase them at a grocery store?

13 Which apples do you think are the organic apples and which do you think are conventional?

Section 4
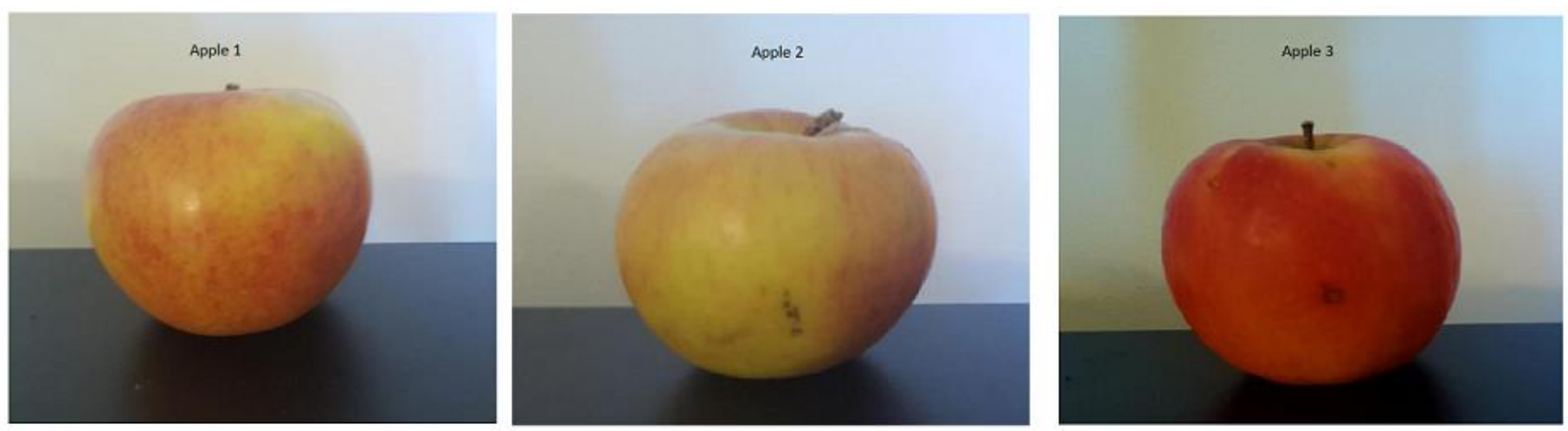
14 Out of these 3 apples, which two do you believe are healthier for you?

Apple 1 and Apple 2 (1)

Apple 1 and Apple 3 (2)

Apple 2 and Apple 3 (3)

15 Out of these three apples, which one would you be more likely to purchase at a grocery store?

Apple 1 (1)

Apple 2 (2)

Apple 3 (3)

Dislike a great deal (4)

\section{Display This Question: \\ If Out of these 3 apples, which two do you believe are healthier for you? Apple 1 and Apple 2 Is Selected}

16 Why did you choose the Apples 1 and 2 in question 10?

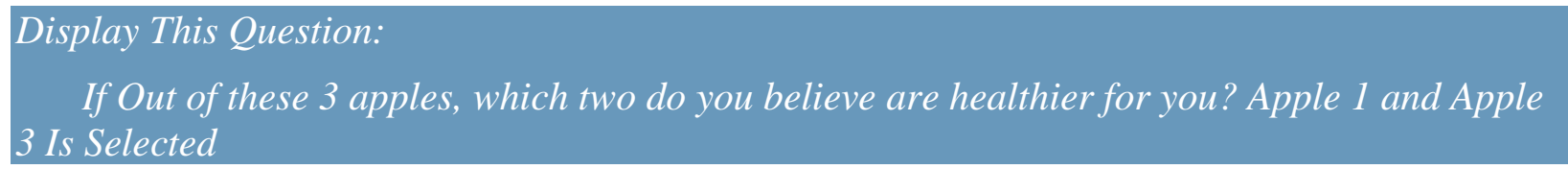

16 Why did you choose Apples 1 and 3 in question 10? 
Display This Question:

If Out of these 3 apples, which two do you believe are healthier for you? Apple 2 and Apple 3 Is Selected

16 Why did you choose Apples 2 and 3 in question 10?

Display This Question:

If Out of these three apples, which one would you be more likely to purchase at a grocery store? Apple 1 Is Selected

17 What would have to be different, if anything, about the apples you said you would not purchase in a grocery store (Apple 2 and 3 ) for you to purchase them at a grocery store?

Display This Question:

If Out of these three apples, which one would you be more likely to purchase at a grocery store? Apple 2 Is Selected

17 What would have to be different, if anything, about the apples you said you would not purchase in a grocery store (Apple 1 and 3 ) for you to purchase them at a grocery store?

\section{Display This Question:}

If Out of these three apples, which one would you be more likely to purchase at a grocery store? Apple 3 Is Selected

17 What would have to be different, if anything, about the apples you said you would not purchase in a grocery store (Apple 1 and 2) for you to purchase them at a grocery store? 
Section 4

18 I am between:

18-20 years old (1)

21-24 years old (2)

$25+$ years old $(3)$

Prefer not to answer (4)

19 Please select your gender

Male (1)

Female (2)

Prefer not to answer (3)

20 My monthly income is between:

$\$ 0-\$ 1000$ (1)

$\$ 1000-\$ 5000(2)$

$\$ 5000-\$ 10000(3)$

More than $\$ 10000$ (4) 
21 I go to the grocery store:

Once a week (1)

Once every two weeks (2)

Once a month (3)

22 I eat produce (fruits and vegetables):

Once a day (1)

Every few days (2)

Once a week or less (3) 


\section{Appendix 2 - Literature Review}

\begin{tabular}{|c|c|c|}
\hline $\begin{array}{l}\text { The Hartman Group. "Consumer Trends in Health } \\
\text { and Wellness." Forbes. Forbes, } 19 \text { November, } \\
\text { 2017. Web. } 6 \text { June 2017. <www.forbes.com> }\end{array}$ & Consumer health & $\begin{array}{l}\text { Consumers are becoming } \\
\text { increasingly particular and aware } \\
\text { about what they put into their bodies }\end{array}$ \\
\hline $\begin{array}{l}\text { Tsui, Bonnie. "Getting Over Our Preference for } \\
\text { Perfect Produce." Newsweek Global, vol. 162, no. } \\
\text { 17, 2014, pp. 1-5 }\end{array}$ & Consumer preference of perfect produd & $\begin{array}{l}\text { Consumers don't want misshappen, } \\
\text { blemished produce and often } \\
\text { overlook produce that aren't } \\
\text { "perfect" }\end{array}$ \\
\hline $\begin{array}{l}\text { Gunders, Dana. "Wasted: How America Is Losing } \\
\text { Up to } 40 \text { Percent of Its Food from Farm to Fork to } \\
\text { Landfill." New York: National Resources Defense } \\
\text { Council, 2012. Print. }\end{array}$ & $\begin{array}{l}\text { Consumer preference of perfect } \\
\text { product/Organic produce is less likely } \\
\text { to be perfect }\end{array}$ & $\begin{array}{l}\text { Food waste is a problem in the US } \\
\text { and often, } 20 \text { to } 50 \text { percent of } \\
\text { produce grown never makes it to the } \\
\text { store }\end{array}$ \\
\hline $\begin{array}{l}\text { Quealy, Kevin and Margot Sanger-Katz. "Is Sushi } \\
\text { 'Healthy'? What About Granola? Where Americans } \\
\text { and Nutritionists Disagree." New York Times. New } \\
\text { York Times, 5 July 2016. Web. 6 June 2017. } \\
\text { <www.nytimes.com> }\end{array}$ & Consumer health & $\begin{array}{l}\text { Nutritionists and the general } \\
\text { population have differing ideas of } \\
\text { what they believe is healthy when it } \\
\text { comes to food. }\end{array}$ \\
\hline $\begin{array}{l}\text { Denton, Carolyn. "Why Does Nutrition Advice } \\
\text { Change?" University of Minnesota. University of } \\
\text { Minnesota, 2016. Web. } 6 \text { June 2017. }\end{array}$ & Consumer health & $\begin{array}{l}\text { There is not one set definition of } \\
\text { nutrition and it often changes. }\end{array}$ \\
\hline $\begin{array}{l}\text { "Over Half of US Consumers Think Organic } \\
\text { Labeling is an Excuse to Charge More." Mintel. } \\
\text { Mintel, } 13 \text { May 2015. Web. 6 June 2017. }\end{array}$ & Organic produce is healthier & $\begin{array}{l}\text { Consumers believe organic produce } \\
\text { is healthier and therefore, believe it } \\
\text { is okay to be charged more for it. }\end{array}$ \\
\hline
\end{tabular}

\begin{tabular}{|c|c|c|}
\hline $\begin{array}{l}\text { "Over Half of US Consumers Think Organic } \\
\text { Labeling is an Excuse to Charge More." Mintel. } \\
\text { Mintel, } 13 \text { May 2015. Web. 6 June 2017. }\end{array}$ & Organic produce is healthier & $\begin{array}{l}\text { Consumers believe organic produce } \\
\text { is healthier and therefore, believe it } \\
\text { is okay to be charged more for it. }\end{array}$ \\
\hline $\begin{array}{l}\text { Stave, Christopher, et al. "Are Organic Foods } \\
\text { Safter than Conventional Alternatives?: A } \\
\text { Systematic Review." Annals of Internal Medicine, } \\
\text { vol. } 157 \text {, no. 5, 2012, pp. } 348-366 .\end{array}$ & Organic produce is healthier & $\begin{array}{l}\text { This was a study conducted to } \\
\text { determine if organic produce is } \\
\text { actually healthy. The results showed } \\
\text { that there is no evidence to support } \\
\text { that claim. }\end{array}$ \\
\hline $\begin{array}{l}\text { Aubrey, Allison and Dan Charles. "Why Organic } \\
\text { Food May Not Be Healthier for You." NPR. NPR, } \\
\text { 4 Sep. 2012. Web. 6 June 2017. <www.npr.org> }\end{array}$ & Organic produce is healthier & $\begin{array}{l}\text { People believe organic food is better } \\
\text { for you than conventional. }\end{array}$ \\
\hline $\begin{array}{l}\text { Strzok, Jesse and Wallace Huffman. "Willingness- } \\
\text { to-Pay for Organic Food Products and Organic } \\
\text { Purity: Experimental Evidence." The Journal for } \\
\text { Agrobiotechnology Management and Economics, } \\
\text { Vol. 18, no. 3, 2012, pp. 345-353. }\end{array}$ & Organic produce is healthier & $\begin{array}{l}\text { People are more willing to pay more } \\
\text { for organic produce }\end{array}$ \\
\hline $\begin{array}{l}\text { de Hooge, Ilona, et al. "This Apple is Too Ugly for Me! } \\
\text { Consumer Preference for Suboptimal Food Products in } \\
\text { the Supermarket and at Home." Food Quality and } \\
\text { Preference, vol. 56, no. 56, 2017, pp. 80-92. }\end{array}$ & $\begin{array}{l}\text { Consumer preference to perfect } \\
\text { product }\end{array}$ & $\begin{array}{l}\text { If the produce is miscolored, } \\
\text { consumers are less likely to choose } \\
\text { that produce over something that is } \\
\text { aesthetically perfect. }\end{array}$ \\
\hline $\begin{array}{l}\text { Loebnitz, Natascha, Geertje Schuitmea, and Klaus } \\
\text { Grunert. "Who Buys Oddly Shaped Food and Why? } \\
\text { Impacts of Food Shape Abnormality and Organic } \\
\text { Labeling on Purchase Intentions." Psychology and } \\
\text { Marketing, vol. 32, no. 4, 2015, pp. 408-421. }\end{array}$ & $\begin{array}{l}\text { Consumer preference to perfect } \\
\text { product }\end{array}$ & $\begin{array}{l}\text { Consumers are influenced by } \\
\text { extreme abnormalities in produce } \\
\text { and less likely to purchase } \\
\text { blemished produce over normal } \\
\text { produce. }\end{array}$ \\
\hline
\end{tabular}

